\title{
Productivity and Nutrient Uptake of Soybean (Glycine max) - Onion (for seed) (Allium cepa) Cropping Systems as Influenced by Integrated Nutrient Management Practices
}

\author{
Vishakha B. Pohare*, D. W. Thawal, Lina D. Shinde and A. B. Kamble
}

Dept. of Agronomy, Mahatma Phule Krishi Vidyapeeth, Rahuri, District Ahemadnagar, Maharashtra (413 722), India

\section{Corresponding Author}

Vishakha B. Pohare

e-mail: vishakhapohare89@gmail.com
Article History

Article ID: IJEP0233

Received in $26^{\text {th }}$ January, 2018

Received in revised form $26^{\text {th }}$ February, 2018

Accepted in final form $17^{\text {th }}$ March, 2018

\begin{abstract}
A field experiment was carried out at PGI Research Farm, MPKV, Rahuri, Dist. Ahemadnagar (MS) during 2014-15 and 2015-16 to study the effect of INM on growth and yield on soybean-onion (for seed) crop sequence. Application of 100\% RDF to preceding crop reported significantly higher values for growth and yield attributes, seed yield $\left(25.86,27.5 \mathrm{q} \mathrm{ha}^{-1}\right)$ in soybean. The succeeding crop of onion (for seed) too showed a similar trend. The nutrient uptake in soybean- onion (for seed) found highest in $100 \%$ RDF however, it was found at par with $50 \%$ RDN through CF+50\% RDN through VC followed by the treatment 50\% RDN through CF+50\% RDN through FYM during both the years and nutrient balance was found highest in $25 \%$ RDF+25\% RDN through VC+25\% RDN through FYM+25\% RDN through NC. After two years completion it was concluded that, combined application of 50\% RDN ( $\left.25 \mathrm{~kg} \mathrm{ha}^{-1}\right)$ through CF+50\% RDN through VC (19.5 t ha-1) or FYM (46 t ha $\left.{ }^{-1}\right)$ to kharif soybean followed by $100 \%$ RDN (100 kg ha-1) through CF to rabi onion (for seed) along with recommended dose of phosphorus and potassium to both the crops is necessary for getting higher yield and soil health in soybean-onion (for seed) crop sequence.
\end{abstract}

Keywords: FYM, NC, nutrient uptake, onion seed, RDF, Soybean, VC

\section{Introduction}

Soybean [Glycine max (L.) Merill] is an important oilseed crop having worldwide adaptation. It is the richest source of protein (40\%) and oil (20\%). There is an apprehension that the use of chemical fertilizers over the years might impair the soil fertility. Continuous use of chemical fertilizers is leading reduction in the crop yield and resulted in imbalance of nutrients in the soil, which has adverse effects on soil health. Use of organic manures alone or in combination with chemical fertilizers will help to improve physico-chemical properties of the soils, efficient utilization of applied fertilizers for improving seed yield and seed quality. Organic manures provide a good substrate for the growth of microorganisms and maintain a favorable nutritional balance and soil physical properties (Maheshbabu et al., 2008). It is recognized that combined source of organic matter and chemical fertilizers play a key role in increasing the productivity of soil (Thakur et al., 2011).

The area under onion cultivation is constantly increasing every year to meet the increasing demand of domestic as well as foreign market. Out of total seed requirement only $20 \%$ has been made available from the organize sector and the rest $80 \%$ is met from the farmers own seed. These leads to production of low quality seed therefore, it is necessary to expand area under seed production. The seeds which are produced properly give uniform germination, rapid root and shoot growth and reduced weed. Onion is grown for seeds. Good seed is the basis for any crop production. Onion seed is poor in keeping quality and loose viability within short period hence it is necessary to produce in every year and use the same for bulk production.

Onion is among the vegetables that response well to nutrients. Its productivity depends on use of optimum fertilizer doses and if not adequately fertilized, considerable yield reduction is apparent as well as indiscriminate use of fertilizers has an adverse effect on crop physiology, soil health and environment. Thus, it becomes important tool for improving productivity as well as quality of onion seed. It is noteworthy to account that, nutrient management for onion seed crop is less attended aspect by seed agencies, scientists and farmers. The fertilizer dose for onion seed crop has not been standardized. Therefore, there is need to undertake planned and elaborative research work on seed production.

The inclusion of legume in cropping sequence is one of the important components of system for saving of fertilizers which are now-a-days costly inputs. Integrated nutrient management plays vital role in improving soil fertility and yield potential of crops through optimization of benefits from all possible sources in an integrated manner i.e. use of organic 
and inorganic fertilizers, such practice is not only achieved sustained production and productivity but also economical and ecofriendly. Significant contribution has been made by many research workers on integrated nutrient management in respect of soybean and onion seed production crop alone; however, keeping these points in view a field experiment on integrated nutrient management for soybean-onion (for seed) cropping sequence.

\section{Materials and Methods}

A field experiment was carried out at Post Graduate Institute Research Farm, Central Campus, Mahatma Phule Krishi Vidyapeeth, Rahuri, Dist. Ahemadnagar (MS) during 201415 and 2015-16. Soil of the experimental plot was clayey in texture analyzing low in available nitrogen (226.12 kg ha-1), medium in available phosphorus (18.20 kg ha-1) and high in potassium content ( $\left.358.33 \mathrm{~kg} \mathrm{ha}^{-1}\right)$. Total soluble salt content in soil (Electrical conductivity) was normal $\left(0.21 \mathrm{dSm}^{-1}\right)$, the soil was moderately alkaline in reaction $(\mathrm{pH} 8.19)$ and the corresponding numerical values for bulk density and maximum water holding capacity are $1.34 \mathrm{mg} \mathrm{m}^{-3}$ and 32.46 $\%$, respectively.

The experiment was laid out in split plot design with three replications. The main plot treatments were applied to kharif soybean comprised of five sources viz., $T_{1}-100 \%$ Recommended dose of fertilizer (RDF), $\mathrm{T}_{2}-50 \%$ recommended dose of nitrogen (RDN) through chemical fertilizer $(\mathrm{CF})+50 \%$ recommended dose of nitrogen (RDN) through Farmyard manure (FYM), $\mathrm{T}_{3}-50 \%$ recommended dose of nitrogen (RDN) through chemical fertilizer (CF)+50\% recommended dose of nitrogen (RDN) through Vermicompost (VC), $\mathrm{T}_{4}-50 \%$ recommended dose of nitrogen (RDN) through chemical fertilizer (CF)+50\% recommended dose of nitrogen (RDN) through Neem cake (NC), $T_{5}-25 \%$ recommended dose of nitrogen (RDN) through chemical fertilizers (CF) $+25 \%$ recommended dose of nitrogen (RDN) through Farmyard manure (FYM)+25\% recommended dose of nitrogen (RDN) through vermicompost (VC) $+25 \%$ recommended dose of nitrogen (RDN) through Neem cake (NC). The residual effect of the integrated nutrient sources applied to kharif soybean was tested in the succeeding rabi onion (for seed). Three fertilier levels as sub plot treatments to onion (for seed) which comprised viz., $\mathrm{F}_{1}-75 \%$ RDN through chemical fertilizer, $\mathrm{F}_{2}-100 \%$ RDN through chemical fertilizer, $\mathrm{F}_{3}-125 \%$ RDN through chemical fertilizer.

As per the treatments, organic manures were applied 15 days before sowing and incorporated through land preparation in the soil; and the nutrient levels of recommended dose of fertilizer were applied broadcast and incorporated into the soil during final seed bed preparation. Urea, single superphosphate and muriate of potash were used as sources of $\mathrm{N}, \mathrm{P}$ and $\mathrm{K}$ respectively for supplying the levels RDF. Soybean (JS-335) was sown @ $75 \mathrm{~kg} \mathrm{ha}^{-1}$ in $30 \mathrm{~cm}$ rows during the second fortnight of July in all the 2 years of experimentation. The seeds were treated with cultures of rhizobium (Bradyrhizobium japonicum) and phosphate solubilizing bacteria (PSB) (Pseudomonas striata) before sowing.

After emergence of seedlings, these were thinned manually to maintain a plant population of $0.33 \mathrm{mha}^{-1}$. The crop was irrigated by surface flooding as and when dry spells occurred. On an average 4 irrigations were given during the entire crop growing period in different years of experimentation. Two manual weedings were carried out at 21 and 35 days after sowing (DAS) and inter-cultivation was done by running a plough between the rows twice after each manual weeding to facilitate proper aeration of the root zone and to overcome compaction during manual weeding. All the growth and yield parameters were recorded at physiological maturity (84 DAS), whereas observations on the nodule numbers and their biomass were recorded at flowering and the crop was manually harvested, threshed and seed yields were recorded. After the harvest of soybean, the land was harrow and levelled without disturbing the lay-out. The recommended dose of fertilizer of onion (for seed) (100-50-50 kg N-P-K $\left.\mathrm{ha}^{-1}\right)$ in the form of urea, diammonium phosphate and muriate of potash was given uniformly to all the plots. Onion bulb ('Phule samarth') was planted in $60 \mathrm{~cm}$ rows using a bulb rate of $2700 \mathrm{~kg} \mathrm{ha}^{-1}$ in the second fortnight of December in all the years, and the crop was raised with normal agronomic practices. All the growth and yield parameters were recorded at physiological maturity (90 DAS). The crop was manually harvested, threshed and the yield was recorded. The soil samples were collected from each plot after the harvest of onion (for seed), after 2 years of cropping system, at 0-30 $\mathrm{cm}$ depth and analyzed using standard procedures. The net return and benefit:cost $(\mathrm{B}: \mathrm{C})$ ratio were computed using the prevailing market rates and prices for the inputs and the seed of soybean and wheat. The data recorded were analyzed as per analysis of variance technique for split plot design and presented as mean data of 2 years.

\section{Results and Discussion}

\subsection{Performance of soybean}

Application of $100 \%$ RDF to soybean produced significantly higher number of pods plant ${ }^{-1}$, number of seeds plant and 100 seed weight and it was at par with 50\% RDN through CF+50\% RDN through VC and 50\% RDN through CF+50\% RDN through FYM during both the years. (Table 1). Among integrated sources significantly highest number of pods plant $^{-1}$, number of seeds plant ${ }^{-1}$ and seed weight plant ${ }^{-1}$ of soybean was found in treatment 50\% RDN through CF+50\% RDN through VC followed 50\% RDN through CF+50\% RDN through FYM than rest of treatments. The least values were observed with the 25\% RDF through CF+25\% RDN through VC+25\% RDN through FYM+25\% RDN through NC during both the years. This was mainly due to combined application of organic manures improved soil physical, chemical and biological environment of soil for favorable crop growth 
Table 1: Effect of nutrient-management practices on growth, yield attributes and yield of soybean (mean data of 2 years)

\begin{tabular}{|c|c|c|c|c|c|c|c|c|c|c|c|c|c|c|c|c|}
\hline \multirow[t]{2}{*}{$\mathrm{T}$} & \multicolumn{2}{|c|}{$\begin{array}{l}\text { Plant height } \\
(\mathrm{cm})\end{array}$} & \multicolumn{2}{|c|}{$\begin{array}{l}\text { No. of pods } \\
\text { plant }^{-1}\end{array}$} & \multicolumn{2}{|c|}{$\begin{array}{c}\text { No. of } \\
\text { seeds pod }\end{array}$} & \multicolumn{2}{|c|}{$\begin{array}{l}\text { Seed weight } \\
\text { plant-1 (g) }\end{array}$} & \multicolumn{2}{|c|}{$\begin{array}{l}100 \text { seed } \\
\text { weight }(\mathrm{g})\end{array}$} & \multicolumn{3}{|c|}{ Seed yield ( $q$ ha $^{-1}$ ) } & \multicolumn{3}{|c|}{ Straw yield $\left(\mathrm{q} \mathrm{ha}{ }^{-1}\right)$} \\
\hline & 2014 & 2015 & 01 & 15 & 2014 & 201 & 2014 & 2015 & 2014 & & & & P & 4 & & \\
\hline $\mathrm{T}_{1}$ & $51.1 \mathrm{c}$ & 02 & & & & Ju & & .73 & 21 & & .60 & 28.86 & 0.25 & 3.22 & 33.75 & \\
\hline $\mathrm{T}_{2}$ & 0.0 & .72 & כ2, & & 2.30 & 'I & 12.52 & 2 & 0 & 3 & 7 & 3 & 0 & 14 & 33.59 & 32.86 \\
\hline $\mathrm{T}_{3}$ & 50.6 & 3.31 & 45.53 & 2.21 & 2.69 & 2.76 & 12.84 & 4.53 & 15.98 & 16.68 & 5.84 & 28.73 & 7.79 & 2.55 & 33.73 & 33 \\
\hline $\mathrm{T}_{4}$ & 44.7 & 46.97 & 40.74 & 48.39 & 2.49 & 2.58 & 11.98 & 13.30 & 15.19 & 15.63 & 25.18 & 27.07 & 26.12 & 30.46 & 33.02 & 31. \\
\hline $\mathrm{T}_{5}$ & 43.25 & 44.62 & 38.16 & 46.70 & 2.36 & 2.47 & 11.45 & 12 & 5 & 02 & 2 & 30 & 35 & 32 & 31.03 & 30.18 \\
\hline$* *$ & 1.10 & 1.01 & 1.13 & 1.20 & 0.06 & 0.06 & 0.23 & 0.33 & 0.28 & 0.3 & 0.40 & 0.48 & 0.2 & 0.42 & 0.40 & 0.41 \\
\hline & 3.18 & 2.93 & .27 & 3.46 & 0.16 & 0.17 & 0.67 & 0.96 & 0.80 & 1.09 & 1.35 & 1.38 & 1.34 & 1.20 & 1.17 & 1.16 \\
\hline
\end{tabular}

T: Treatment; P: Pooled; $T_{1}: 100 \%$ RDF; $T_{2}: 50 \%$ RDN through CF+50 \% RDN through FYM; $T_{3}: 50 \%$ RDN through CF+50\% RDN through VC; $T_{4}: 50 \%$ RDN through $\mathrm{CF}+50 \%$ RDN through NC; $\mathrm{T}_{5}: 25 \% \mathrm{RDN}$ through $\mathrm{CF}+25 \% \mathrm{RDN}$ through $\mathrm{FYM}+25 \%$ RDN through VC+25\% RDN through NC; **: SEm \pm ; *: CD ( $p=0.05)$;

and yield also provide all essential plant nutrients including micronutrients to accelerate the respiratory process that increase cell permeability which encourage proliferous root system resulting better absorption of water and nutrients from lower layers thus resulting in higher yield attributes. FYM, VC and neem cake alone was not able to adequately supply of plant nutrients specially phosphorus (Patra and Sinha, 2014). These results are in corroborated with those reported by Kathiresa et al. (1999); Pattanashetti et al. (2002), Thanunathan et al. (2002); Ghosh et al. (2005).

Seed yield $\left(1.48 \mathrm{t} \mathrm{ha}^{-1}\right)$, straw yield $\left(4.06 \mathrm{t} \mathrm{ha}^{-1}\right)$ recorded significantly higher with application of $100 \%$ RDF through CF than rest of treatments. Among integrated sources 50\% RDN through $\mathrm{CF}+50 \% \mathrm{RDN}$ through VC. It was closely followed by application of $50 \%$ RDN through $\mathrm{CF}+50 \%$ RDN through FYM. As there was ideal condition for soil microflora due to application of VC and FYM along with CF increased availability of nutrients, there was improvement in both growth and yield attributes, which in turn might have increased the yield of soybean. This combination play key role in enhancing the efficiency of utilization of native as well as applied nutrients and augment the availability of certain micronutrients and improved the activities of soil microorganisms involved in nutrient transformation and fixation which leading to higher seed yield and yield components. Similar results were postulated by Rana and Badiyala (2014); Singh et al. (2014), Maheswari and Sivasakthivelan (2015); Singh et al. (2015.

\subsection{Residual effect on onion (for seed)}

Growth attributes (number of flower stalk bulb ${ }^{-1}$, height of flower stalk, diameter of flower stalk, diameter of umbel and dry matter accumulation plant ${ }^{-1}$ ), yield attributes and seed yield was significantly influenced due to residual effect of nutrients applied to the preceding soybean during both the years and number of flower of onion (for seed) with the application of $100 \%$ RDF to previous season soybean than different nutrient treatments during both the years however, it was at par with treatment 50\% RDN through CF+50\% RDN through VC and $50 \%$ RDN through CF+50\% RDN through FYM (Table 2). Among the integrated treatments 50\% RDN through $\mathrm{CF}+50 \%$ RDN through VC and 50\% RDN through CF+50\% RDN through FYM show residual effect due to slow and gradual release of nutrients and preceding soybean is a legume crop having considerable potential to fix atmospheric nitrogen that can be utilized for succeeding post rainy season crop thus might have improved the performance of onion (for seed). (Table 3). Similar results are in accordance with Bhatia and Pandey (1991); Shrawan Singh et al. (2004); Reddy and Reddy (2005); Pawar et al. (2009); Khang et al. (2011); Verma et al. (2011). Among the fertilizer levels to rabi onion (for seed), application of $125 \%$ RDN through CF $(5.05,5.45$ and $5.25 q$ ha $\left.{ }^{1}\right)$ was recorded significantly higher seed yield over $75 \%$ RDN through CF and at par with $100 \%$ RDN through CF $(4.96,5.35$ and $5.16 \mathrm{q} \mathrm{ha}^{-1}$ ) during both the years and pooled respectively. Might be due to added higher amount and readily supply of nutrients helped the increase in the availability of major nutrients and thereby leading to higher yield attributes of onion (for seed) reflecting higher seed yield. The present results are in conformity with those of Similar result reported by, Patil et al. (2007); Adagale et al. (2009); Khang et al. (2011), Jawadagi (2012); Singh et al. (2014).

\subsection{Performance of nutrient uptake and nutrient balance in soybean-onion (for seed) cropping system}

The maximum nutrient uptake of the soybean-onion (for seed) cropping system observed in 100\% RDF over 50\% RDN through CF+50\% RDN through VC and 50\% RDN through $\mathrm{CF}+50 \% \mathrm{RDN}$ through FYM at harvest during both the years. Among integrated sources application of $50 \%$ RDN through CF+50\% RDN through VC higher uptake over 50\% RDN through $\mathrm{CF}+50 \%$ RDN through FYM at harvest during both the years (Table 3, 4). The better response to $50 \%$ RDN through CF $50 \%$ 
Table 2: Nutrient balance sheet as influenced by different treatments after harvest of soybean-onion (for seed) crop sequence (2014-15)

\begin{tabular}{|c|c|c|c|c|c|c|c|c|c|c|c|c|c|c|c|}
\hline \multirow[t]{2}{*}{1} & \multicolumn{3}{|c|}{$\begin{array}{l}\text { Initial nutrients } \\
\qquad\left(\mathrm{kg} \mathrm{ha}^{-1}\right)\end{array}$} & \multicolumn{3}{|c|}{$\begin{array}{l}\text { Nutrients applied to } \\
\text { crop }\left(\mathrm{kg} \mathrm{ha}^{-1}\right)\end{array}$} & \multicolumn{3}{|c|}{$\begin{array}{l}\text { Nutrients uptake by } \\
\text { crops }\left(\mathrm{kg} \mathrm{ha}^{-1}\right)\end{array}$} & \multicolumn{3}{|c|}{$\begin{array}{l}\text { Soil available nutrients } \\
\text { after harvest }\left(\mathrm{kg} \mathrm{ha}^{-1}\right)\end{array}$} & \multicolumn{3}{|c|}{$\begin{array}{l}\text { Nutrients Balance } \\
\qquad\left(\mathrm{kg} \mathrm{ha}^{-1}\right)\end{array}$} \\
\hline & $\mathrm{N}$ & $P$ & $\mathrm{~K}$ & $\mathrm{~N}$ & $P$ & $\mathrm{~K}$ & $\mathrm{~N}$ & + & $\mathrm{K}$ & $\mathrm{N}$ & $P$ & $\mathrm{~K}$ & $\mathrm{~N}$ & $P$ & $\mathrm{~K}$ \\
\hline $\mathrm{T}_{1} \mathrm{~F}_{1}$ & 226 & 18 & 358.00 & 25.00 & 55.00 & 42.00 & 209.14 & 25.12 & 92.25 & 22.23 & 19.12 & 357.08 & -80.37 & 28.77 & -49.3 \\
\hline$T_{1} F_{2}$ & 226 & 18 & 358.00 & 150.00 & 55.00 & 42.00 & 211.36 & 25.83 & 93.06 & 227.53 & 20.83 & 364.83 & -62.89 & 26.34 & -57.89 \\
\hline $\mathrm{T}_{1} \mathrm{~N}_{3}$ & 226 & 18 & 358.00 & 175.00 & 55.00 & 42.00 & 212.10 & 26.16 & 93.39 & 234.73 & 21.54 & 371.44 & -45.83 & 25.31 & -64.83 \\
\hline $\mathrm{T}_{2} \mathrm{~F}_{1}$ & 226 & 18 & 358.00 & 125.00 & 44.32 & 64.70 & 194.02 & 21.12 & 83.79 & 214.22 & 15.09 & 348.31 & -57.23 & 6.11 & -9.41 \\
\hline $\mathrm{T}_{2} \mathrm{~F}_{2}$ & 226 & 18 & 358.00 & 150.00 & 44.32 & 64.70 & 196.00 & 21.79 & 84.53 & 15.08 & 15.91 & 348.77 & -35.09 & 4.62 & -10.60 \\
\hline $\mathrm{T}_{2} \mathrm{~N}_{3}$ & 226 & 18 & 358.00 & 175.00 & 44.32 & 4.70 & 196.44 & 22.05 & 84.74 & & 16.85 & 350.98 & & 3.43 & 02 \\
\hline $\mathrm{T}_{3} \mathrm{~F}_{1}$ & 226 & 18 & 358.00 & 125.00 & 48.64 & 61.30 & 200.59 & 23.05 & 87.92 & 221.21 & 16.06 & 352.91 & -70.80 & 27.53 & -21.5 \\
\hline $\mathrm{T}_{3} \mathrm{~F}_{2}$ & 226 & 18 & 358.00 & 150.00 & 48.64 & 1.30 & 202.58 & 23.67 & 88.58 & 13 & 17.38 & 42 & -50.71 & 58 & -26.70 \\
\hline $\mathrm{T}_{3} \mathrm{~F}_{3}$ & 226 & 18 & 358.00 & 175.00 & 48.64 & 61.30 & 203.07 & 23.86 & 88.79 & 229.69 & 18.94 & 368.02 & -31.77 & 3.84 & -37.51 \\
\hline $\mathrm{T}_{4} \mathrm{~F}_{1}$ & 226 & 18 & 358.00 & 125.00 & 40.94 & 48.38 & 178.95 & 17.84 & 76.42 & 35 & 13.55 & 334.44 & -36.31 & .55 & -4.48 \\
\hline $\mathrm{T}_{4} \mathrm{~F}_{2}$ & 226 & 18 & 358 & 150 & 40.94 & 48. & 182 & 18. & 77 & 03 & 48 & 71 & -18 & 1 & -11.89 \\
\hline $\mathrm{T}_{4} \mathrm{~F}_{3}$ & 26 & 18 & 500 & 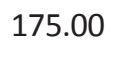 & 4 & 8 & 2 & 19.06 & 7 & 0.42 & 16.36 & 344.01 & 1.46 & 3.52 & (5.0. \\
\hline $\mathrm{T}_{5} \mathrm{~F}_{1}$ & 226 & 18 & 358. & 1 & 38 & 6 & 0 & 1 & 6 & 8 & 12 & 328 & 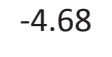 & 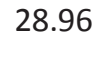 & 4 \\
\hline $\mathrm{T}_{5} \mathrm{~F}_{2}$ & 226 & 18 & 358.00 & 150.00 & 38.57 & 66.16 & 164.03 & 15.25 & 69.34 & 203.94 & 13.35 & 332.82 & 8.03 & 7.97 & 22.0 \\
\hline $\mathrm{T}_{5} \mathrm{~F}_{3}$ & 226 & 18 & 358.00 & 175.00 & 38.57 & 66.16 & 164.77 & 15.41 & 69.54 & 209.94 & 14.58 & 332.47 & 26.29 & 26.58 & 22.15 \\
\hline GM & 226 & 18 & 358.00 & 150.00 & 45.49 & 56.51 & 190.74 & 20.92 & 82.42 & 216.96 & 16.53 & 348.86 & -31.70 & 26.05 & -16 \\
\hline
\end{tabular}

Table 3: Effect of nutrient-management practices on growth, yield attributes and seed yield of onion (mean data of 2 years)

$T$ Plant height No. of Height of Diameter of Diameter Seed weight 1000 seed Seed yield ( $q$ ha $^{-1}$ ) (cm) flower stalk flower stalk flower stalk of umbel bulb-1 $(\mathrm{g})$ weight $(\mathrm{g})$ $\begin{array}{llll}\text { bulb }^{-1} & (\mathrm{~cm}) & (\mathrm{cm}) & (\mathrm{cm})\end{array}$

\begin{tabular}{|c|c|c|c|c|c|c|c|c|c|c|c|c|c|c|c|c|c|}
\hline & 14 & 15 & 14 & 015 & 14 & 15 & 014 & 015 & 014 & 2015 & 014 & 015 & 014 & 015 & 014 & 2015 & 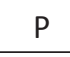 \\
\hline$T_{1}$ & .35 & 2 & 43 & .62 & 2.0 & .92 & 1. & 3 & 15 & 8.49 & 3.90 & 32 & .98 & 1 & 5.70 & 6.13 & .92 \\
\hline $\mathrm{T}_{2}$ & .35 & .00 & 5.98 & 6.19 & 68.71 & .19 & 1.42 & 18 & 80 & 19 & & 7 & & & 22 & 2 & 42 \\
\hline $\mathrm{T}_{3}$ & 77.55 & 0.35 & & & 69.77 & 2.15 & 1.44 & & & & & 15.51 & 3.91 & & 5.41 & 5.96 & \\
\hline $\mathrm{T}_{4}$ & 73.49 & 5.00 & & 6.01 & 6 & 68.08 & 1. & 1 & 7.20 & 7.54 & 10.82 & 12.25 & 3.46 & 3.82 & 4.16 & 4.39 & 4.200 \\
\hline$T_{5}$ & 71.3 & 75.45 & 5.58 & 6 & 64.4 & .71 & 1. & +5 & 66 & 6. & 0.15 & 50 & 3 & 3.72 & 3.13 & 3.38 & 3.25 \\
\hline$* *$ & 1.04 & 1.0 & .15 & 069 & 19 & 1.09 & 0.02 & 0.01 & 0.13 & 0.25 & 40 & 0.38 & 0.06 & ).09 & 17 & .18 & 0.21 \\
\hline & 79.35 & וכ. & 0.51 & 26 & 90 & DO & 0.06 & 0.05 & 42 & 33 & 30 & 1.24 & .20 & 0 & ככנ & 59 & 0.04 \\
\hline$F_{1}$ & 75.08 & 77.79 & .63 & 5.6 & 65.69 & 7.79 & 1.33 & 42 & .71 & 7.05 & 11.23 & 3.36 & 5 & .88 & 16 & .49 & 4.52 \\
\hline$F_{2}$ & 75.84 & 78.71 & 6.19 & 6 & 69.01 & .38 & 1.45 & 1.50 & 95 & 8.29 & 12.57 & 32 & 3.74 & 4 & 4.96 & 35 & 5.16 \\
\hline $\mathrm{F}_{3}$ & 75.91 & 79.25 & 6.32 & 0 & 69.70 & 72.06 & 49 & 2 & 8.04 & 8.36 & 12.78 & 46 & 3.78 & 5 & 5.05 & 5.45 & 5.25 \\
\hline ** & 0.23 & 0.21 & 0.04 & 0.07 & $0 . \angle 0$ & 0.24 & 0.01 & 0.005 & 0.04 & 0.05 & 0.08 & 0.07 & 0.02 & 0.04 & 0.04 & 0.05 & 0.00 \\
\hline & 0.70 & 0.61 & 0.14 & 0.22 & 0.78 & 0.71 & 0.03 & 0.014 & 0.13 & 0.16 & 0.25 & 0.21 & 0.06 & 0.11 & 0.14 & 0.15 & 0.17 \\
\hline & NS & NS & Sig. & Sig. & Sig. & Sig. & NS & NS & Sig. & Sig. & Sig. & Sig. & NS & NS & Sig. & Sig. & NS \\
\hline
\end{tabular}

$\mathrm{F}_{1}: 75 \%$ RDN through $\mathrm{CF} ; \mathrm{F}_{2}: 100 \%$ RDN through $\mathrm{CF} ; \mathrm{F}_{3}: 125 \%$ RDN through $\mathrm{CF} ;{ }^{* * *}$ : Interaction (T×F) 
RDN through VC and FYM may be ascribed on the higher nutrient content and lower $\mathrm{C}$ : $\mathrm{N}$ ratio leading to increased nutrient uptake by cropping system. Ramesh et al. (2009) indicated that soil organic carbon, available N, P, K status and biological activity of soil in terms of dehydrogenase enzyme were significantly improved in integrated treatment compared to chemical fertilizers when studied under soybean-onion (for seed) cropping system.

The significantly highest soil available $\mathrm{N}, \mathrm{P}$ and $\mathrm{K}$ were recorded in $100 \%$ RDF over $50 \%$ RDN through CF+50\% RDN through VC and $50 \%$ RDN through CF+50\% RDN through FYM during both the years (Table 3, 4).

The data on net gain and loss of nutrients after completion of second cycle of soybean-onion (for seed) system are presented in Table 3, 4.

The application of different nutrient sources to soybean showed a negative balance of nitrogen and potassium in soil and as far as phosphorus balance is concerned showed positive balance as compare to its initial value. The actual nitrogen balance in soybean-onion (for seed) cropping system showed maximum negative nitrogen balance in treatments treated with $100 \%$ RDF followed by $50 \%$ RDN through CF $50 \%$ RDN through VC. As regarding the potassium negative balance was maximum under $100 \%$ RDF followed by $50 \%$ RDN through CF $+50 \%$ RDN through VC. Phosphorus showed positive balance as compare to its initial value maximum phosphorus built up recording $25 \%$ RDN through $\mathrm{CF}+25 \% \mathrm{RDN}$ through FYM $+25 \%$ RDN through VC+25\% RDN through NC followed by application of application of 50\% RDN through $\mathrm{CF}+50 \%$ RDN through VC while minimum in $\mathrm{CF}+50 \%$ RDN through NC.

In treatment receiving $25 \%$ RDN through CF+25\% RDN through $\mathrm{FYM}+25 \%$ RDN through $\mathrm{VC}+25 \%$ RDN through NC recorded high build up of $\mathrm{P}$ nutrients which might be due to more availability of nutrients from sources, whereas, highest negative balance of $\mathrm{N}$ was in $100 \%$ RDF through CF due to continuous removal of nutrients by both the crops. The negative balance of nitrogen might be due to fixation of atmospheric nitrogen by the soybean, onion (for seed) fulfilling the excess nitrogen requirement. It also indicate that there is need to apply the nitrogen to exploit the full potential yield of soybean-onion (for seed) crop sequence.

Table 4: Nutrient balance sheet as influenced by different treatments after harvest of soybean-onion (for seed) crop sequence (2015-16)

\begin{tabular}{|c|c|c|c|c|c|c|c|c|c|c|c|c|c|c|c|}
\hline \multirow[t]{2}{*}{$\mathrm{T}$} & \multicolumn{3}{|c|}{$\begin{array}{l}\text { Initial nutrients } \\
\qquad\left(\mathrm{kg} \mathrm{ha}^{-1}\right)\end{array}$} & \multicolumn{3}{|c|}{$\begin{array}{l}\text { Nutrients applied } \\
\text { to crop }\left(\mathrm{kg} \mathrm{ha}^{-1}\right)\end{array}$} & \multicolumn{3}{|c|}{$\begin{array}{l}\text { Nutrients uptake by } \\
\text { crops }\left(\mathrm{kg} \mathrm{ha}^{-1}\right)\end{array}$} & \multicolumn{3}{|c|}{$\begin{array}{l}\text { Soil available nutrients } \\
\text { after harvest }\left(\mathrm{kg} \mathrm{ha}^{-1}\right)\end{array}$} & \multicolumn{3}{|c|}{$\begin{array}{l}\text { Nutrients Balance } \\
\qquad\left(\mathrm{kg} \mathrm{ha}^{-1}\right)\end{array}$} \\
\hline & $N$ & & K & & & $k$ & $N$ & & & & & & $N$ & D & K \\
\hline$F_{1}$ & & & & & & & & & & & & & & & \\
\hline $\mathrm{F}_{2}$ & & & & & & & & & & & & & & & \\
\hline $\mathrm{N}_{3}$ & 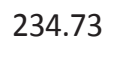 & & & & & & & & & & & & & & \\
\hline $\mathrm{T}_{2} \mathrm{~F}_{1}$ & 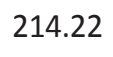 & & & & 52. & 4.96 & & & & & & & & & \\
\hline $\mathrm{T}_{2} \mathrm{~F}_{2}$ & 215.0 & 91 & 1877 & & & 5 & & & & & 17.34 & & & & \\
\hline $\mathrm{T}_{2} \mathrm{~N}_{3}$ & 22132 & 1685 & 5098 & & 52.78 & 6496 & 20 & 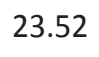 & - & 0 & 18.28 & & & & \\
\hline $\mathrm{T}_{3} \mathrm{~F}_{1}$ & 121 & 506 & 6 ৭1 & & 56.91 & & & -1 & & & & & & & \\
\hline $\mathrm{T}_{3} \mathrm{~F}_{2}$ & 224.13 & . & & & & & & & & & 18 & & & & \\
\hline $\mathrm{T}_{3} \mathrm{~F}_{3}$ & 229.69 & 3.94 & 8.02 & 5 & 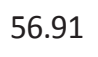 & 61. & & 26.08 & 96.10 & 11 & 20.37 & & & 29.40 & \\
\hline $\mathrm{T}_{4} \mathrm{~F}_{1}$ & 208.3 & .55 & 4.44 & 5 & .26 & 48.73 & 185.00 & 19.37 & 85.10 & 66 & 14.98 & 33 & -67 & 23.46 & \\
\hline $\mathrm{T}_{4} \mathrm{~F}_{2}$ & 212.0 & 5.48 & 40.71 & 50 & 1.26 & 8.73 & 188.55 & 20.31 & 86.32 & 17.49 & 16.91 & 343 & -44 & 22.52 & \\
\hline $\mathrm{T}_{4} \mathrm{~F}_{3}$ & & 1 & 1 & 5 & & 3 & & 20 & & 48 & 11 & & & & \\
\hline $\mathrm{T}_{5} \mathrm{~F}_{1}$ & & & & & & 3 & & 16 & & & 14 & & & 31.55 & \\
\hline $\mathrm{T}_{5} \mathrm{~F}_{2}$ & & & & & & & & & & & & & & 31.12 & \\
\hline $\mathrm{T}_{5} \mathrm{~F}_{3}$ & 209. & 1 & & & & & & 17.09 & & 9.03 & 16.01 & 335.58 & -3.55 & 30.96 & -14.35 \\
\hline GM & 16.96 & .53 & 8.86 & 50 & 51.68 & 5.70 & 198.46 & 22.60 & 89.75 & 25.12 & 17.98 & 351.92 & -56.62 & 27.63 & -36.11 \\
\hline
\end{tabular}

\section{Conclusion}

The soybean-onion seed cropping sequence under INM recorded the higher yield contributing characters and yield of kharif soybean- rabi onion (for seed) higher in $50 \%$ RDN through $\mathrm{CF}+50 \%$ RDN through VC and 50\% RDN through CF $50 \%$ RDN through FYM . Application of $100 \%$ RDF through CF recorded significantly higher nutrient uptake by kharif soybean than rest of treatments and in rabi onion (for seed) 
was significantly higher in $125 \%$ RDN.

\section{References}

Adagale, S.V., Masalkar, S.D., Pandure, B.S., 2009. Effect of integrated nutrient management on growth and yield of onion seed production. The Asian Journal Horticulture 44(2), 484-487.

Dixit, S.P., 1997. Response of onion (Allium cepa L.) to nitrogen and farm yard manure in dry temperate high hill of H.P. Indian Journal of Agricultural Sciences 67, 222-223.

Ghosh, P.K., Bandyopadhyay, K.K., Singh, A.B., 2005. Effect of integrated Nutrient management on matter production, Water use efficiency and productivity of soybean [Glycine max L. Merill] on vertisols of central Indian Journal of Oilseed Research 22(2), 289-292.

Jawadagi, R.S., Basavaraj, N., Patil, B.N., Naik, B.H., Channappagoudar, B.B., 2012. Effect of different sources of nutrients on growth, yield and quality of onion (Allium cepa L.) Cv. Bellary red. Karnataka Journal of Agricultural Sciences 25(2), 232-235.

Khang, V.T., 2008. Development of organic farming package for soybean-onion cropping sequence. Ph.D. thesis submitted to Mahatma Phule Krishi Vidyapeeth, Rahuri, MS, India.

Maheshbabu, H.M., Hunje, R., Biradar, N.K., Babalad, H.B., 2008. Effect of organic manures on plant growth, seed yield and quality of soybean. Karnataka Journal of Agricultural Sciences 21(2), 219-221.

Maheswari, T.U., Sivasakthivelan, P., 2015. Studies on the effect of certain organic inputs in yield maximization and analysis of rhizosphere microflora in Okra Cv. Arka Anamika. Indo-Asian Journal Multidisciplinary Research 1(4), 310-314.

Pattanashetti, V.A., Agasimani, C.A., Babalad, H.B., 2002. Effect of organic and fertilizer levels on growth, yield and yield attributes of soybean intercropped with maize in Northen Transitional tract of Karnataka Journal of Oilseed Research 19(1), 113-114.

Ramesh, P., Panwar, N.R., Singh A.B., Ramana, S., 2009. Production potential, nutrient uptake, soil fertility and economics of soybean (Glycine max L. Merrill) based cropping system under organic, chemical and integrated nutrient management practices. Indian Journal of Agronomy 54(3), 278-283.

Rana, R., Badiyala, D., 2014. Effect of integrated nutrient management on seed yield, quality and nutrient uptake of soybean (Glycine max L. Merrill) under mid hill conditions of Himachal Pradesh. Indian Journal of Agronomy 59(4), 641-645.

Shivakumar, B.G., Ahlawat, I.P.S., 2008. Integrated nutrient management in soybean (Glycine max L. Merrill)-wheat (Triticum aestivum) cropping system. Indian Journal of Agronomy 53(4), 273-278.

Singh, S., Yadav, P.K., Singh, B., 2004. Effect of nitrogen and potassium on growth and yield of onion (Allium cepa) Cv. Pusa Red. Haryana Journal of Horticultural Sciences 33(3/4), 308-309. 